ROBERT VOSPER

\title{
A Century Abroad
}

$\mathrm{T}_{\mathrm{H}}$ OVERSEAS RELATIONSHIP of American academic and research libraries has been in the search for books. Thomas Jefferson's zealous skill as a private book collector in Europe not only set the pattern for his later personal efforts in support of the University of Virginia's library; here also was an early, exemplary model available for later "librarians"1 as well as for later university presidents. ${ }^{2}$

In his dramatic letter of September 21,1814 , proffering his private library to the Congress, Jefferson recalled:

While residing in Paris, I devoted every afternoon I was disengaged, for a summer or two in examining all the principal book stores, turning over every book with my own hands, and putting by everything which related to America, and indeed whatever was rare and valuable in every science. Besides this, I had standing orders during the whole time I was in Europe, on its principal book-marts, particularly Amsterdam, Frankfort, Madrid, and London, for such works relating to America as could not be found in Paris. ${ }^{3}$

This would have been between 1784 and 1789, during most of which time he was the American minister to France.

This experience permitted Jefferson then as the founding rector of the University of Virginia, in the last few years of his life, to give meticulous directions -as to language, edition, and price of European books required for the new university library-in a fascinating series of letters to the contracting book agents in Boston, whom he convinced to set up a branch office in Charlottesville. ${ }^{4}$

\section{Early Collection Development}

One does not know the extent to which other American academic libraries in the 1820 s were so carefully searching the European book market, but it is pleasant to recall, as another possible touchstone, that the equally bookish Henry Wadsworth Longfellow, professor of modern languages and librarian of Bowdoin College from 1829 to 1835, was painstaking in purchasing European literature for the library, not many books in all to be sure, but a scholarly selection. In these professional efforts he had the advantage of a European tour, including book buying commissions, fostered by the college in the years just prior to his actual appointment. ${ }^{5}$

But despite such disciplined efforts as those of Jefferson and Longfellow, it was pointed out in the first article in this series that by 1876 , our terminus $a$ $q u o$, even though we have no careful analysis of collections at the time, "library finances were uncertain and gifts played the largest role."6 This resulted in uneven and generally inadequate collections, but it is nonetheless also clear that the importance of British and Eu- 
ropean publications was not underestimated.

The meaty analysis of individual "College Libraries" in the famous 1876 Report on public libraries in the United States not only reminds us of the eighteenth century British gifts of books to Harvard, Yale, and Columbia, but also points out a number of significant European acquisitions at other institutions. Of special note is the fact that Longfellow did not plow a new furrow at Bowdoin because in 1811, shortly after its founding, the college library received a bequest of 4,000 French and Spanish books collected by the Hon. James Bowdoin during his diplomatic mission in Spain.

We also learn from the 1876 Report that the only "considerable donation" received by the University of Michigan Library was "the library of the late Dr. Rau, Professor in the University of Heidelberg, consisting of about 4,000 volumes and 6,000 pamphlets, purchased and presented" by a Detroit citizen. The seminal John C. Green endowment of 1868 at Princeton permitted the purchase of "the library of Trendelenburg, of Berlin, consisting of nearly 10,000 volumes and pamphlets" of classical and philosophical interest.

In 1869 a local friend purchased for the young Northwestern University Library the 20,000 volume private library of a Dr. Schulze, a member of the Prussian ministry of public instruction. And the library of Harvard's Museum of Comparative Zoology was initiated by the 1858 purchase of a Belgian professor's paleontological collection. ${ }^{7}$

Interestingly enough, the most thorough calendaring of the flow of European, particularly German, scholarly book collections to American academic libraries was prepared by a German librarian, Dr. Albert Predeek, for the third volume of the Milkau-Leyh Handbuch der Bibliothekswissenschaft; fortunately, his historical review of
British and American libraries has been translated into English. He specifies important private libraries of nineteenth century German scholars in theology, philology, history, bacteriology, and surgical history that ended up at Andover Theological Seminary, the Chicago Theological Seminary, Adelbert College in Cleveland, New York University, Toronto, Bryn Mawr, Vassar, McGill, Virginia, and George Washington, as well as Harvard, Chicago, Cornell, and Pennsylvania.

This transatlantic flow began early in the nineteenth century and was, of course, but one aspect of the German influence on American scholarship; but during the last third of the century the amount and the importance of the traffic was sufficient to cause concern among German librarians and even in the daily press. ${ }^{8}$ As an episode in bibliothecal history this is mindful of the flush years after World War II when American academic libraries were investing heavily in the en bloc book market in almost all parts of the world.

The nineteenth century German complainants might have enjoyed Stanford's embarrassment over the 1895 purchase of the 7,000 volume philological library of Professor Rudolf Hildebrand. Through an interested Stanford faculty member, friends of the university were asked to contribute toward the purchase price, but Mrs. Stanford herself lodged a direct protest with President David Starr Jordan about the purchase of "that German Library by soliciting subscriptions from my friends and the Trustees." In consequence, some years of effort and ingenuity were required before the cost was covered. ${ }^{9}$

One terse note in the 1876 Report suggests that Rector Jefferson was not the first university founding official to seek out books overseas for a new library: Pennsylvania's first provost, Dr. Smith, brought back books from a 1751 visit to Great Britain, undertaken par- 
ticularly to seek endowment funds. ${ }^{10}$ But Jefferson's involvement and expertise were obviously much more intense and visible. One wonders then whether his approach may have influenced other founding presidents. In any event, it is of significance that two other such great founders did personally involve themselves in the European book market.

The classical example is Andrew Dickson White, the first president of Cornell University, founded in 1865 . One of his first acts as president was to spend time in Europe buying books for his new university, and throughout his tenure he gave the library his personal attention. This was a natural development because throughout his whole adult life books were an intimate and essential passion..$^{11}$

William Rainey Harper, as the founding president of the University of Chicago in 1891, gave that university an early library emphasis. Like White, one of Harper's initial ventures was a trip to Europe to acquire, among other things, library books. Soon after settling in Berlin, he secured "an option for the purchase by the University of the Calvary library, a collection of more than 200,000 books, manuscripts, and pamphlets." Later called the "Berlin Collection," this cost friends of the new university $\$ 45,000.12$

Archibald Cary Coolidge's tenure as Harvard's librarian (1910-1928) came a generation later than the events just mentioned, but his European book buying support for Harvard began in the late nineteenth century and is thus a colorful part of the same story. As an internationally minded, bookish scholar, later librarian, he appears a veritable paragon.

Well-to-do and widely traveled, even while a young instructor in history, Coolidge instituted a series of benefactions to strengthen the Harvard library. In 1895 he purchased as a gift for Harvard "almost the entire contents of a catalogue from Harrassowitz of Leipzig," some 1,371 Slavic titles which amounted to 10 percent of the library's total intake for that year. Similarly generous European purchases, on even a larger scale, continued into the early years of the next century.

Then in the spring of 1905 Coolidge marshaled a program of special significance in the history of library collection building. Having decided to bring together for Harvard 10,000 volumes on German history, to be known as the Hohenzollern Collection, he personally employed a talented young bibliophile, Walter Lichtenstein, later to become Northwestern University's librarian, to undertake "book-buying and book-trading for the Library" in Europe and then to "check off" the books on receipt. $^{13}$

In a certain sense, then, Lichtenstein is a prototype of today's skilled area specialist bibliographers, many of whom do their book buying in the field overseas. This is the same Walter Lichtenstein whose prototypical cooperative book buying trip to South America in 1913-14 was pointed out in an earlier article in this series. ${ }^{14}$

\section{The Book Dealers}

Thus, no matter how uneven the total result, it seems evident that throughout the nineteenth century a number of American academic libraries were involved, at least occasionally, in the international flow of books. This business, for libraries in general, was sufficient to generate advertisements in the earliest volumes of the American Library Journal from New York-based book agents who announced weekly importations from Germany, England, France, and Spain. By the 1890s European publishers and book dealers, especially English and French, were advertising regularly in the Library Journal.

The agency relationship goes back at least to the early London career of the 
forceful and learned Henry Stevens, who primarily served wealthy private collectors but who also had a close relationship with American libraries. For example, during the autumn of 1845 , Stevens' first year in London, Charles C. Jewett, then librarian of Brown University, visited with him, as did Professor J. L. Kingsley, who had $\$ 10,000$ to spend for books for Yale and who left orders with Stevens. "Jewett had bought 3,000 books on the Continent for Brown University, and he also placed his final orders with Henry." 15

From such associations it was natural for Stevens in 1877 to act as host for the group of twenty-one officers and members of the year-old American Library Association who came to London when their British colleagues met to form the Library Association of the United Kingdom. Moreover, Henry Stevens presented a paper at the London conference and was elected to the executive council of the new British group. ${ }^{16}$

In 1864 one of Henry's younger brothers, Benjamin Franklin Stevens, set up his own business in London, thereby establishing the agency firm of B. F. Stevens \& Brown, which continues to serve many American academic libraries today. ${ }^{17}$ The diary of one of B. F. Stevens' assistants, E. C. Bigmore, suggests that as early as 1878 the new firm had instituted a practice, pleasantly familiar to many today, of American commercial tours. 18

The equally durable and faithful German firm of Otto Harrassowitz in Leipzig, later Wiesbaden, became Harvard's agent in 1882 , on the initiative of Justin Winsor, and by 1897 the firm was serving forty American libraries in this way. ${ }^{19}$

This well established confidential relationship between individual American libraries and the overseas book trade was to take on a policy significance of a general nature in the years just after World War II when the Farmington Plan and similar national programs were based in contractual ties with foreign book agents, including the two just mentioned. It was not in fact until those postwar years that the international book procurement activities of American academic libraries moved into a new gear, marked by those very national programs.

The general inadequacy of American research library collections in terms of European publications became a subject of pointed attention at the end of World War I. In 1919 E. C. Richardson of Princeton, a leading internationalist and an early proponent of cooperative effort in resolving the problem, deplored "The Poverty of American Libraries in the Matter of Research Books."20 This appraisal was supported by Yale's Andrew Keogh, who spoke of the "regrettable condition of our scholarly libraries" with regard to both the primary and secondary sources of research. ${ }^{21}$

But an economic depression and other factors, including the lack of an effective organizational structure, prevented any forceful attack on the book poverty problem until another war in the 1940s once again cut American libraries off from the European book market and libraries and thereby reemphasized the gaps in American collections.

In 1919 the American Library Institute, a discussion forum of American library leaders, most of them university librarians, had devoted its conference in Atlantic City to "International Cooperation," but most of the papers dealt with general problems and philosophical attitudes. ${ }^{22}$

\section{Organized Collection Development}

By the time of the second go-around the situation was more optimistic and more practically based. The analog of the ALI session of 1919, the 1946 Princeton Conference, dealt with a variety of specific proposals and could relate many of them to operational or- 
ganizations. ${ }^{23}$ Thus the Association of Research Libraries, which had been established in 1932, was petitioned "to bring the Farmington Plan into effect as soon as possible on an experimental basis." Although ARL had not been intended to manage programs of this nature, it did have the muscle to respond to a clear national need, with results that are too well known to be recounted again here.

However, a few general points should be made. Most pointedly, the high international significance of the Library of Congress Postwar Mission to Europe, and by extension the Farmington Plan, is defined by way of the official statement of Archibald MacLeish, as assistant secretary of state, in 1945 that "the Department of State agrees ... that the national interest is directly affected" by the collective holdings of American libraries. ${ }^{24}$

Secondly, it should be repeated here that another intention of the Library of Congress Mission, in addition to stockpiling European wartime publications, was to foster the revival of the European book trade and national bibliography. Thus the Farmington Plan agency contracts were a source of real support. Mr. Dorn of Harrassowitz has recalled with pleasure the arrival of Keyes Metcalf in Wiesbaden in 1950 on behalf of the Farmington Plan. ${ }^{25}$ This use of foreign book dealers as procurement agents was a distinctive aspect and fundamental policy of the Farmington Plan, often debated but sufficiently successful that Farmington's successor, the National Program for Acquisitions and Cataloging, uses the same mechanism wherever appropriate and feasible. It should also be noted that the Public Law 480 library procurement project has also had a beneficial effect on the foreign book trade and the international relations of libraries.

That neat succession of nationally oriented, cooperative foreign book procurement programs (the LC Mission, the Farmington Plan, PL480, and NPAC) can be identified, I think, as a major effort in the broad field of international relations, an effort that has successfully enriched the coordinate holdings of American research libraries, that has involved many American librarians, directly and indirectly, in overseas activity, and that has had a powerful impact on the book trade, on the development of bibliography, and on the practice of librarianship around the world.

This becomes evident when it is recalled that the National Program for Acquisitions and Cataloging, or the Shared Cataloging Program as it was then called, sparked the imagination of the world library community and in fact fostered the Universal Bibliographic Control program of the International Federation of Library Associations.

It was at the 1966 IFLA conference in The Hague that the president, Sir Frank Francis, declared in his opening address with something less than British understatement:

When I first discussed with the Librarian of Congress and his colleagues just about 12 months ago, their proposal for adopting a system of shared cataloguing to enable them to meet the new assignments laid on them by the United States Congress, I was electrified by the prospects which this new development opened up. I felt we were at least on the edge of the most important break-through in the world of information since the elaboration of rules for cataloguing made clear the basis on which cataloguing procedures should work. ${ }^{26}$

From that perception in 1966 there flowed in short order IFLA's International Cataloguing Secretariat, with its many skillful seminars and publications, and then the International Office for Universal Bibliographic Control, which already is having global impact. ${ }^{27}$ 


\section{INTERNATIONAL BIBLIOGRAPHICAL} Projects

These recent optimistic developments should not entirely obscure the earlier but yet not persistent interest of American research libraries, as well as others, in cooperative cataloging and related bibliographical activity at the international level. The paper that Henry Stevens read in London at the 1877 conference, entitled "Photo-Bibliography; or, a Central Bibliographical Clearinghouse," drew on earlier suggestions of Charles C. Jewett and proposed, in effect, the centralized production of standardized catalog cards that would be universally available for sale..$^{28}$

The time was not yet ripe for so ambitious a project, but another practical American proposal, formally put forward by the American Library Association, did bear fruit when the conference approved the appointment of an English committee to cooperate in making a new edition of the Index to Periodical Literature international in scope, rather than just American. William Frederick Poole himself was present in London to state the case.

When in 1895 the Royal Society of London invited international participation for developing what became the International Catalogue of Scientific Literature, several Americans immediately supported the idea. Herbert Putnam of the Boston Public Library urged librarians to "enter the discussion" so that not only scientists would be involved, and both Clement W. Andrews of the John Crerar Library and Joseph C. Rowell, librarian of the University of California, prepared supportive papers for the December 1895 ALA conference. ${ }^{29}$ The following year Dr. John Shaw Billings of the New York Public Library, on behalf of ALA, was one of the official U.S. representatives to the international conference convened by the Royal Society in London to discuss possibilities.
Thereafter, however, American involvement centered officially in the Smithsonian Institution.

On the other hand, the International Institute of Bibliography (IIB) in Brussels, progenitor of the International Federation for Documentation (FID), which also developed in 1895 , attracted virtually no American involvement in its activities throughout its early career. Despite the Institute's adoption of the Dewey classification system and despite the persistent involvement and efforts of Richardson of Princeton, especially during the 1920s when he was chairman of ALA's Committee on Bibliography, American librarianship remained "aloof to the documentalists." ${ }^{30}$

\section{The Conference Circuit}

The events of 1876 quickly set in motion a sequence of international library conferences in which American academic librarians, albeit not in large numbers, played their part. Not infrequently this was a leading part.

1877

It was only fitting that an official ALA delegation should go to London in October 1877 to attend the Conference of Librarians, mentioned earlier with reference to Henry Stevens. This meeting was convened for the purpose of founding an English association of librarians, and it was to be international in scope because the 1876 founding of ALA had been observed with great interest in England.

Leader of the adventuresome expedition was, of course, Justin Winsor, recently appointed librarian of Harvard and also president of ALA. Among the group were Reuben Aldridge Guild, librarian of Brown University, Melvil Dewey of Amherst, Charles Ammi Cutter, sometime cataloger at Harvard, Annie R. Godfrey of Wellesley College 
Library, who was to become Mrs. Dewey, J. Tingley of Allegheny College, and W. L. Ropes of Andover Theological Seminary Library. That lively and propitious expedition has been reported engagingly in an article that should be required reading during the Anglo-American centennial years of 1876 and $1877 .^{31}$

\section{3}

In 1893, under Melvil Dewey's presidency, the ALA conference was held in Chicago in connection with the World's Columbian Exposition, which included extensive American and European publishers' exhibits and at least two library displays. One was prepared by ALA and one was sent from Germany and supervised in Chicago by an assistant librarian from the University of Kiel. This exposition also fostered several professional congresses, including one that was announced as the "World's Congress of Librarians." As the Library Journal editorialized, that title was justified "rather by the invitations which have been sent out than by the response received." ${ }^{2}$

In addition to about three hundred Americans there were only fifteen foreign visitors in the registration list, including five Canadians. However, a number of those invited from abroad sent papers that were subsequently published, including some that were indicative of academic library interests. The eminent librarian of the University of Göttingen encouraged more efficient arrangements internationally for the exchange of duplicates, for interlibrary loan, for the distribution of library reports, and for the assured cataloging by each nation of its own publications and library treasures ${ }^{33}$ His colleague from the Royal University Library in Halle reported on the successful development of reciprocal agreements in Europe for the lending of manuscripts, called on American libraries to join in, and proposed an organized program for the gradual photographic reproduction of important manuscripts; ${ }^{34}$ that proposal was eventually referred to ALA's Committee on Cooperation where it apparently disappeared.

1897

Four years later, for their twentieth anniversary in 1897, the British were considerably more successful in projecting a truly international conference, no doubt because of the proximity of Europe and the British colonial ties. In the initial planning stages it was thought of as a joint Anglo-American meeting, but the larger scheme of a Second International Library Conference (the first having been that of 1877) soon developed. Fourteen governments sent delegates, primarily, of course, from Europe, but including Japan, Australia, India, and Jamaica.

Out of the total roll of 641 , there was an impressive delegation of over eighty from the United States, led, as in 1877, by Justin Winsor, who was a vice-chairman of the London conference, and including also Mr. Dewey. However, as against the 1877 meeting, the American academic attendance was less impressive, although there were representatives from Cornell, Wellesley, Nashville, and the University of Illinois.

The only paper by an American academic librarian was that of E. C. Richardson, who was unable to attend in person. The other American papers were by public librarians, including William H. Brett, then president of ALA, on "Freedom in Public Libraries," by which he meant free access to the shelves in both academic and public libraries, a concept which a British critic called "simply a plea for anarchy." ${ }^{35}$

\section{0}

In connection with an international exposition in Paris in 1900, the French convened at the Sorbonne a Congrès International des Bibliothécaires, which 
brought together librarians from most of the European countries, and from as far afield as Chile, Cuba, and Mexico. Herbert Putnam, by then at the Library of Congress, was one of the vicepresidents of the congress, but was apparently unable to attend. However, Mary Wright Plummer, director of libraries of Pratt Institute and later president of ALA, was another official American delegate and presented a paper on cooperation between public and school libraries in the United States.

The American delegation of about twenty was the largest foreign group and included E. C. Richardson; Addison Van Name of Yale; Clement W. Andrews of the John Crerar Library; Joseph C. Rowell of the University of California; Florence Kane, librarian of Bryn Mawr; and G. T. Little of Bowdoin. An unusual paper describing the organization and operation of American libraries and including a bibliography, was presented by a French participant, E.-Daniel Grand, who had visited widely among American libraries of all kinds between 1894 and 1898 when he was apparently taking an A.M. degree at Harvard. An ALA exhibit "showing the progress and condition of American libraries," prepared by the New York State Library, was included at the Paris exhibition. ${ }^{36}$

\section{4}

Once more in 1904, ALA, under Putnam's presidency, convened in connection with a world's fair, this time the St. Louis Louisiana Purchase Exposition. The international component was noticeably more significant than in 1893 , with delegates from seventeen countries and a still useful body of published papers.

One group reported on library practice, including the state of research libraries, in several countries; another group dealt in specific terms with international bibliographic activities (e.g.,
The International Catalogue of Scientific Literature, the Concilium Bibliographicum, and the IIB in Brussels); and another group was concerned with cataloging practice and the theory of classification. Among the authors of papers were Richardson, William Coolidge Lane of Harvard, Charles Martel of the Library of Congress, the vice-librarian of Uppsala, and the principal librarian of the Danish Royal Library. The most intriguing paper was that of Dr. Guido Biagi, director of the Laurentiana in Florence, who foresaw the "graphophone" as a major new device for recording and disseminating information and thus for transforming libraries: "Books will no longer be read, they will be listened to," he said. ${ }^{37}$

\section{0 and 1923}

Two congresses in tandem at Brussels in 1910, one on bibliography and documentation in connection with the IIB, and the other of archivists and librarians, drew over fifty Americans. Their participation, however, was relatively slight, and a very few university librarians were in the group, which did include, interestingly enough, the Misses Carrie Watson, librarian of the University of Kansas, and Belle Sweet, librarian of the University of Idaho. ${ }^{38}$

The International Congress of Librarians and Bibliophiles in Paris in 1923 apparently brought no Americans, possibly because of the pressures of postwar activity at home, but ALA was officially represented by W. Dawson Johnston, recently appointed librarian of the new American Library in Paris. ${ }^{39}$

\section{6 and 1927}

However, three years later another period of major ALA involvement in international affairs got underway. In the heady atmosphere of the new Czechoslovakia, another International Congress of Librarians and Bibliophiles was convened in Prague in late June 1926, 
with some 700 in attendance, involving a large and interesting representation from Central and Eastern Europe.

ALA dispatched Carl Milam to take greetings and to invite participation in the forthcoming ALA fiftieth anniversary conference to be held in Philadelphia and Atlantic City. In Prague, W. Dawson Johnston, by then the Library of Congress official representative in Europe, chaired a session on international questions, and Mary Parsons, resident director of the lively library school in connection with the American Library in Paris, presented a paper on library education and the exchange of teachers and students.

M. Gabriel Henriot, president of the French library association and a regular teacher in the American library school in Paris, officially proposed the establishment of a permanent library committee to be representative of the several national library associations. He even suggested that such a body might find a home in connection with the American Library in Paris. ${ }^{40}$

Henriot's suggestion was pursued at the ALA conference that fall in a special session chaired by William Warner Bishop of the University of Michigan, chairman of ALA's International Relations Committee. The European delegation on that occasion requested ALA officially to canvass the several national associations, looking toward formal discussions to be held the next year in Edinburgh at the Library Association's fiftieth anniversary conference. Those 1927 Edinburgh discussions were successful in establishing what we now know as the International Federation of Library Associations. ${ }^{41}$

ALA's 1926 conference had a strong international flavor, with just over one hundred registrants from twenty-two foreign countries, and it has left us in the proceedings an interesting body of papers dealing with library developments in such distant places as China,
Palestine, the Soviet Union, and Japan. ${ }^{42}$

The following year eighty-two Americans joined the British for their jubilee conference. E. C. Richardson, by then emeritus, was in attendance, and Andrew Keogh of Yale presented a lantern slide lecture on the new Sterling Library, but the American academic attendance in general was limited, and the conference papers did not generally deal with academic library matters.

Carl Milam, projecting a new international thrust of ALA, was a leader in the proceedings, and it is of interest that Mr. Dewey, who was scheduled to present a major address, was kept at home by ill health. This led to a regretful editorial comment that the British "had hoped to assure ourselves that he was a man and not a system." 43

\section{IFLA}

From 1927 onward the story of international library conferences is pretty much the story of IFLA, which will be duly memorialized in historical publications, including an intended article on U.S. participation, during IFLA's own jubilee year of 1977.44

A few comments on the American role are requisite here. At the outset, as has been indicated, the American interest was crucial. Dr. Bishop was the official ALA delegate; he was immediately elected vice-chairman, and then served as president of IFLA from 1932 through 1935. Unhappily, the depression almost aborted the Chicago meeting which he scheduled for 1933.

Out of respect for Bishop, a small group of eminent European librarians did come to Chicago, but a formal meeting was held later that year in Avignon. Full-scale meetings of IFLA did not cross the Atlantic until 1967 (Toronto) and 1974 (Washington, D.C.). Fortunately, though, Bishop's IFLA career concluded grandly when he presided in 1935 over IFLA's Second 
World Congress of Libraries and Bibliography in Madrid; the first, of course, had been held in Rome and Venice in 1929.

In its early years IFLA activity centered in its governing body, the International Library Committee, quite limited in number, formed by individual delegates from national associations. For some years after Bishop's day, American participation was rather intermittent, and, of course, World War II closed everything down from 1940 to 1947. Milton Lord served as vice-president from 1947 to 1949 , and then beginning in 1953 there developed a regular pattern of American (latterly North American) vice-presidents (Douglas Bryant, 1953-1957; Jack Dalton, 19581965; Foster Mohrhardt, 1966-1971; and Robert Vosper, 1972-1977).

In the burgeoning days of library expansion beginning about 1960 , the numbers of official delegates and observers at annual meetings, including Americans, increased sharply and forced reconsideration of the organizational structure and meeting format of IFLA. Our own academic involvement in the professional work of the organization was usefully advanced in 1963 when the Association of Research Librarians (ARL) officially joined as a national member alongside ALA, and from about the same time the Library of Congress has been regularly represented.

The dynamic involvement of ARL and the Library of Congress in international procurement and cataloging activities after World War II has been detailed already in this article, and that story will have made it evident that the closer participation since about 1963 on the part of both organizations in IFLA affairs has been a significant international move on the part of American research libraries.

It must be obvious, of course, that this article does little justice to the total international program of the Library of Congress, as well as of the national libraries for medicine and agriculture; that is a full story in its own right. ${ }^{45}$

It should be recalled here also that in September 1964 ARL undertook its one overseas junket when the Carnegie Corporation of New York financed, for a selected group of eleven ARL representatives, a joint meeting with the equivalent British body, the Standing Conference of National and University Libraries (SCONUL) at the University of Hull. This was a useful time for the American visitation because of the recent rise of several new British universities. The joint meeting found a number of matters of common interest and proposed a reciprocal meeting on this side. Unfortunately, that did not work out, but it was made possible for the Honorary Secretary of SCONUL to visit American libraries and meet with ARL the following year. ${ }^{46}$

That experience reminds one also that in 1956 ACRL happily arranged for 130 U.S. librarians to fly and float from Miami Beach to Havana for a gala session with their Cuban counterparts. ${ }^{47}$ Not only was the intermingling appreciated on both sides, but the timing was providential in that the acquaintanceship assisted a few Cuban librarians in moving to this country a few years later when life became too complicated for them at home. This is not to overlook the fact that for many years through its committee structure, its conference papers, and the pages of College \& Research Libraries, ACRL has opened up international horizons to its members.

\section{INDIVIDUAL COMMITMENT}

It will be evident that during its first half century and more ALA's international involvement focused around the energetic commitment of a few individuals, notably Winsor of Harvard, Dewey, Richardson of Princeton, Putnam of the Library of Congress, and 
Bishop of Michigan. This was true even after ALA decided at Montreal in 1900 to formalize its activities in a standing Committee on International Cooperation, which in 1906 became the Committee on International Relations.

Richardson was appointed founding chairman in 1901, Putnam succeeded him in 1911, and Bishop took over in 1926, serving until 1934. During those years a few other research library leaders recurrently served on the committee: John Shaw Billings, W. C. Lane, C. W. Andrews, T. W. Koch, Andrew Keogh, and C. H. Gould. Richardson, in fact, continued as a member of the committee until the mid-1930s, a term matched only by that of ALA-founding father Richard Rogers Bowker, a man of varied international interests, who was a member of the first committee in 1901 and apparently served until his death in 1933 .

It is of some interest that, even in the more intensive days after the 1942 establishment of ALA's International Relations Board with its complex corporate responsibilities, the following academic librarians served terms as chairman, up into the 1960s: Flora Belle Ludington, Keyes D. Metcalf, Luther Evans, Douglas Bryant, William Dix, Jack Dalton, Raynard Swank, and Marion Milczewski.

But most of the international involvement discussed thus far, it will have been noted, was that of research library officials as individuals, often to be sure as representatives of the ALA, rather than an institutional commitment of American research libraries. University librarians if interested conducted their own international relations. The institutional overseas involvement in those days was pretty much limited to the foreign procurement activities of particular libraries, by way of purchase or publications exchange. It is then perhaps reasonable to speak of a long era of personal ambassadorship stretching from 1876 and even earlier, up until World War II and its aftermath.

The strength of the personal involvement is particularly demonstrable in the careers of two university librarians, Richardson and Bishop. The latter, with some reason, has been termed "our first international librarian."48 Yet from a chronological viewpoint that title might well be given to Richardson.

\section{Ernest Cushing Richardson}

Ernest Cushing Richardson's long professional career and his impressive contributions to bibliography, historical studies, and interlibrary cooperation, have been well reported, but the international component has been somewhat slighted. He himself recalled in a significant article that in his earlier years he "fell into the habit of using the four months' vacation for the study of European libraries," and that, "when I went to Princeton in 1890 , the prin-

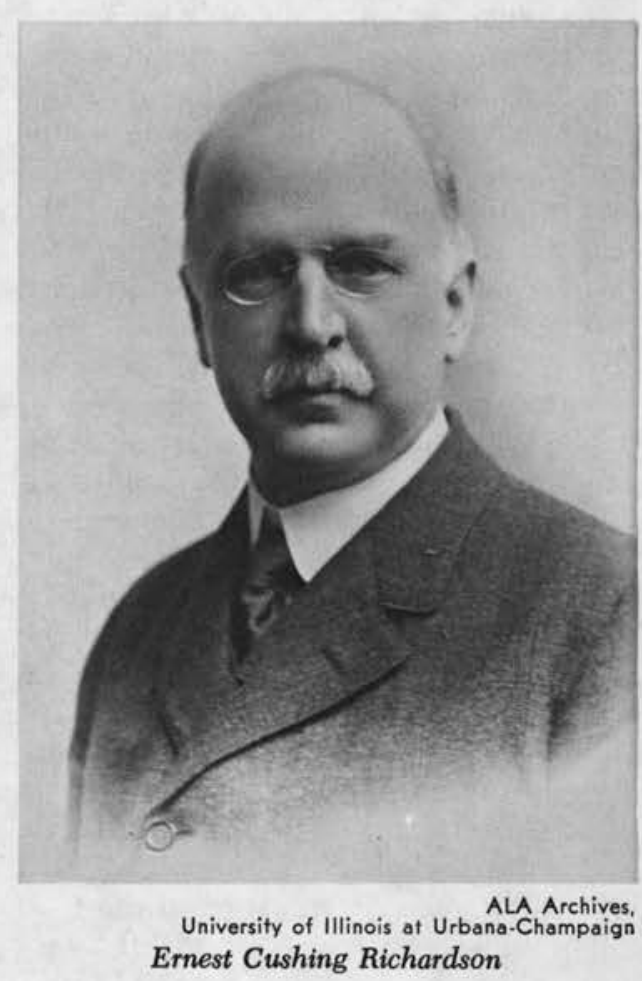


ciple of frequent bibliographical journeys was accepted by the President and the Trustee Committee as part of a recognized policy." 49

In addition to his long service with ALA's Committee on International Relations, Richardson was also the first chairman of the Committee on Bibliography established in 1922-23, a position he held for the next decade. He used that forum to speak and write frequently and forcefully about the importance of international bibliographical cooperation and to urge American participation in a variety of undertakings, such as the International Catalogue of Scientific Literature, the Concilium Bibliographicum in Zurich, and the various bibliographical activities of the Institute of Intellectual Co-operation established by the League of Nations in 1924. Most particularly he was the American spokesman, albeit not very successfully, in behalf of the IIB in Brussels, the recurrent conferences of which he frequently attended. ${ }^{50}$

Richardson's prescience in this field is best illustrated by this statement in a 1901 symposium on Libraries in the Twentieth Century:

Co-operation has been the watchword of American libraries during the latter part of the nineteenth century, but it is only beginning to be a matter of universal scope. It is beginning, however, and the century will doubtless see China, India, and Africa as well as Europe and South America using common bibliographical standards and uniting to produce a universal catalog of world literature. ${ }^{51}$

IFLA's UBC program in the last quarter of the century confirms that optimism. However, Richardson was often a lone voice and apparently not always successful in generating organized support in behalf of his interests, despite his strong convictions about the necessity for institutional cooperation, nationally and internationally.

\section{William Warner Bishop}

William Warner Bishop, however, who it happens disagreed with his mentor Richardson's evaluation of IIB, was notably effective in organizational affairs, as is evident from his IFLA career discussed earlier. As with Richardson, Bishop had close and learned ties with Europe, beginning with an 1898 fellowship in the American School of Classical Studies in Rome, where he, of course, became acquainted with the Vatican Library.

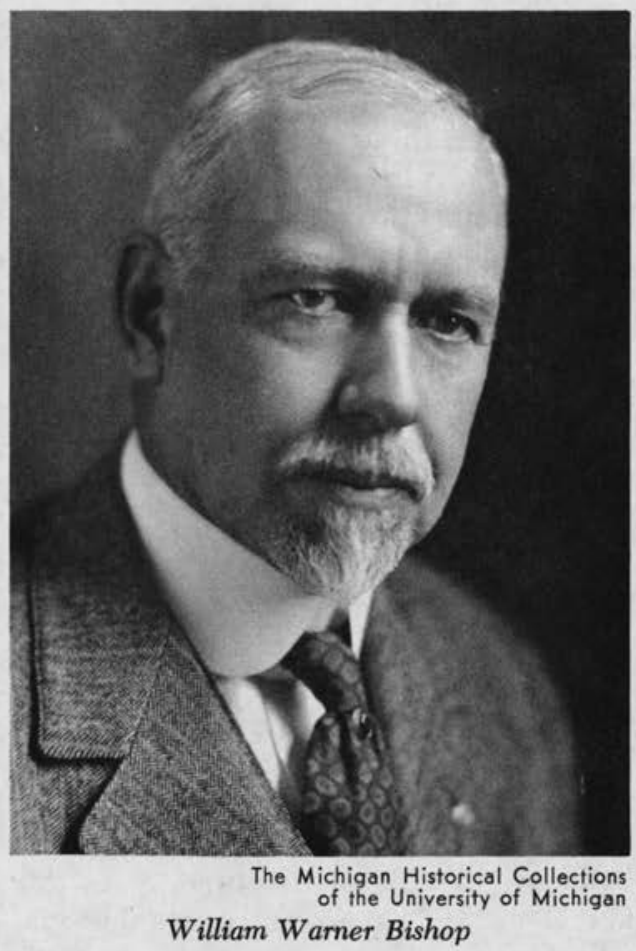

Unlike Richardson, Bishop did not have the private means to support recurrent European visits, but both the University of Michigan, by way of book-buying ventures and sabbatical leaves, and latterly the Carnegie Corporation did facilitate his active international library career. ${ }^{52}$

Beyond his IFLA work, Bishop's most enduring overseas contribution was his service as head of the project, fostered 
by the Carnegie Endowment for International Peace, to recatalog and in other ways modernize the Vatican Library in Rome, between 1927 and $1935 .^{53}$ Instituted from Rome by Msgr. (later Cardinal) Tisserant, himself an active participant in early IFLA and other international library affairs, the Vatican project is one of the great monuments of American overseas library activities and is also a worthy forerunner of the modern project-oriented style that marks almost all post-World War II international activities.

The project brought four Vatican librarians (as well as others in later years) to the United States for practical internship at the Library of Congress and for formal library training courses at Columbia and Michigan. Under Bishop's leadership the project also took an impressive American team of experts, including Charles Martel and J. C. M. Hanson of the Library of Congress, to Rome where they were joined by Milton Lord, then Librarian of the American Academy in Rome.

As a result, the Vatican Library was enabled, not only to produce a summary index of its manuscripts and a record of its incunabula, but also to reconstruct the reading rooms, install a Snead stack and elevators, and establish a library training school. A central component was the adoption of LC cards for the basic catalog record. It was Bishop's opinion at the time that "this agreement on cataloging principles ... will advance the practice of international cataloging at least fifty years." 54

\section{The Age of Technical Assistance}

With the development of the Farmington Plan and related projects following on World War II, as has been mentioned earlier, and with the establishment of ALA's International Relations Board and International Relations Office in 1942 , we come into a far more complex modern period when American overseas library activity is highly organized, is based in a variety of interinstitutional compacts, involves large numbers of individuals, is fostered by large injections of external funding, and is oriented toward a multitude of complex projects. The long pleasant era of personal international relations and of junkets to paper-reading conferences draws to an end.

Not only is this more recent experience so rich as to make a brief analysis overly simplistic, but it becomes even more difficult than in the earlier period to extricate the academic and research library experience from the generality of the international relations of American librarianship.

Fortuitously, Beverly J. Brewster's analysis of American Overseas Library Technical Assistance has just apeared and provides thorough documentation of almost all aspects of this busy period. ${ }^{55}$

That report, with its many useful tabulations of overseas projects, supports the impression that during these recent postwar years American academic libraries and librarians have continued to play a major role in the overall library technical assistance effort abroad, as fostered by the active involvement of U.S. government agencies, UNESCO and other international bodies, the American private foundations, ALA, and individual universities. Still needed, as Brewster concludes, is qualitative evaluation of the impact of these multifarious activities on library development and on librarians, here and abroad. ${ }^{56}$

One gap in the record is the busy concentration in the 1950 s and 1960 s on automation developments, with a flurry of groups and individuals from abroad looking into the American academic library experience with computers. Evaluation is needed here as well, because too frequently, at least in the earlier years, the American experience may 
have been misleading.

As against the earlier period, a striking change since the 1940 s is the widespread involvement of large numbers of individual librarians, not just chief librarians, in all manner of international programs-as book selection specialists, often in the field, as expert consultants abroad, and as lecturers and teachers in almost all corners of the world, as well as in service at home to a complexity of committees of ALA, ACRL, and ARL. Another basic change, as already suggested, is the institutional involvement of academic and research libraries in large-scale programs, such as Farmington, as well as in bilateral technical assistance compacts between individual American universities and foreign counterparts.

\section{CURRent Issues}

With the close of the 1960s this rich adventure went into a sharp decline, in considerable measure because of the depressed American economy, the consequent drying up of government support for both overseas projects and academic programs at home, and the concurrent redirection of foundation support into other fields. But equally debilitating was the American malaise stemming from the Vietnam war and related unhappy experiences overseas, which led many intellectuals, including librarians, to suspect that any international involvement would be tainted with cultural imperialism or worse. More than symbolic of this distressing period was the virtual cessation, fortunately only temporarily, of official ALA international activity.

Ironically, this American withdrawal occurred just as the need for a new style of extensive international library cooperation was being sharply perceived in other parts of the world. Just when the ALA membership was expressing disapproval of organized overseas programs, a new and lively International and Com- parative Librarianship Group was being fostered by membership initiative in the Library Association of Great Britain, and today the Library Association and its members are noticeably busy overseas, with particular support from the British Council.

Even more impressive has been the recent surge of involvement on the part of Third World countries in international library affairs, as focused particularly through a reorganized IFLA. Of about eighty-five countries thus involved, over half are now so-called developing countries, and this is a phenomenon of the 1970s. The call from libraries in those countries today is not so much for aid, in the older sense of technical assistance, as it is for joint participation in professional activities requiring a larger forum.

In evaluating the American effort of the previous three decades, one might well ask what part that effort may have played in stimulating this refreshing movement of the 1970 s and readying libraries for it, taking into account also the parallel British activity overseas as well as the understandable ambitions of new nationalism in the Third World.

A major focus of interest and work in the international field today is on IFLA's rapidly developing program for Universal Bibliographic Control, and next in the pipeline is what IFLA calls Universal Access to Publications. Both concepts may seem to involve overweening ambition, yet UBC already has demonstrably sparked the imagination and generated the support of librarians throughout the world, including the developing world.

Thus the center of attention is no longer American librarianship and U.S. aid; the center of attention is the international forum and professional programs in which all libraries in all countries have both an obligation and a stake. In many aspects of modern librarianship we are no longer a creditor 
nation, but rather we have much to learn from our colleagues overseas in fields ranging from library architecture to library automation, from library education to national library planning.

In the field of international standards for bibliographic control, stemming from IFLA's UBC program, for example, rapid strides are being made toward firm decisions that will fundamentally affect the design of national bibliographies and the ready transfer of bibliographic information. Yet for lack of adequate U.S. participation in the early design effort, decisions may be made that American libraries will find it difficult to live with. It thus behooves the research libraries of the country to increase the level and quantity of American involvement in the professional and technical work of IFLA. This will require not so much chief librarians as experienced staff experts in cataloging, automation, networking, and the like.

Fortunately, there are some bright indicators on the horizon. The Council on Library Resources has put firm support behind IFLA; the Library of Congress is aware of the need for effective participation; and since IFLA opened up the possibility of formal associate membership for libraries in recent years, a commendable number of American research libraries and library schools have so joined. Now they must take up the option of personal involvement.

E. C. Richardson observed half a century ago that the solution to many of our local problems is in large measure dependent on international cooperation. ${ }^{57}$ It is now urgent that we take his observation seriously.

\section{ReFERENCES}

1. Randolph G. Adams has called Jefferson the "Father of American Librarianship" in his Three Americanists (Philadelphia: Univ. of Pennsylvania Pr., 1939), p.95.

2. I have recently treated this matter at greater length in a Clark Library seminar paper now in press.

3. William Dawson Johnston, History of the Library of Congress, Vol. I, 1800-1864 (Washington, D.C.: Govt. Print. Off., 1904), p.70.

4. Thomas Jefferson, Jefferson's Ideas on a University Library, edited by Elizabeth Cometti (Charlottesville: Tracy McGregor Library, Univ. of Virginia, 1950).

5. Roger Michener, "Henry Wadsworth Longfellow: Librarian of Bowdoin College, 1829-1835," Library Quarterly 43:215-26 (July 1973).

6. Edward G. Holley, "Academic Libraries in 1876" College \& Research Libraries 37:23 (Jan. 1976).

7. U.S. Department of the Interior, Bureau of Education, Public Libraries in the United States of America: Their History, Condition, and Management, Special Report, Part I (Washington, D.C.: Govt. Print. Off., 1876), p.60-126. Hereafter cited as 1876 Report.

8. Albert Predeek, A History of Libraries in Great Britain and North America, translated by Lawrence S. Thompson (Chicago:
American Library Assn., 1947), see esp. p.100-102.

9. Ralph W. Hansen, "The Stanford University Library: Genesis 1891-1906," Journal of Library History 9:147-48 (April 1974).

10. 1876 Report, p.117.

11. Andrew Dickson White, Autobiography (New York: Century Co., 1905), V. 1, esp. p.262-64, 308-309, 338, 360, 440.

12. Thomas W. Goodspeed, William Rainey Harper, First President of the University of Chicago (Chicago: Univ. of Chicago Pr., 1928), p.117-18.

13. William Bentinck-Smith, "Archibald Cary Coolidge and the Harvard Library," Harvard Library Bulletin 21:237, 240-44 (July 1973).

14. David C. Weber, "A Century of Cooperative Programs among Academic Libraries," College \& Research Libraries 37:207 (May 1976).

15. Wyman W. Parker, Henry Stevens of Vermont, American Rare Book Dealer in London, 1845-1886 (Amsterdam: N. Israel, 1963), p.54-55.

16. Ibid., p.295-97.

17. G. Manville Fenn, Memoir of Benjamin Franklin Stevens (London: Chiswick Press, 1903), p.111.

18. Lawrence Clark Powell, ". . . and Brown"; A Chronicle of B. F. Stevens \& Brown, Ltd., Library and Fine Arts Agents of 
London, with Emphasis on the Years Since 1902 (London: privately printed, 1959), p.3.

19. Richard Dorn, "Otto Harrassowitz, Buchhandlung-Verlag-Antiquariat: The First Century," Harvard Library Bulletin 21: 365-74 (Oct. 1973).

20. E. C. Richardson, General Library Co-operation and American Research Books (Yardley, Pa.: F. S. Cook, 1930), p.13-16.

21. Andrew Keogh, "Our Library Resources as Shown by Some Government Needs in the War," Library Journal 44:504-507 (1919).

22. American Library Institute, Papers and Proceedings, 1919 (Chicago: 1920).

23. American Library Association, Board on Resources and International Relations Board, Conference on International Cultural, Educational, and Scientific Exchanges (Chicago: American Library Assn., 1947).

24. Edwin E. Williams, Farmington Plan Handbook (Assn. of Research Libraries, 1953), p.19.

25. Dorn, "Otto Harrassowitz," p.371-72.

26. International Federation of Library Associations, Actes du Conseil Général, 32 session, The Hague, 1966 (The Hague: Nijhoff, 1967), p.27.

27. The basic document is Dorothy Anderson, Universal Bibliographic Control (Pullach/ München: Verlag Dokumentation, 1974).

28. Conference of Librarians, London, 1877, Transactions and Proceedings (London: Chiswick Press, 1878), p.70-81.

29. Clement W. Andrews, "International Bibliography of Scientific Literature," Library Journal 20:c25-c27 (Dec. 1895); Joseph C. Rowell, "A Subject Index to Science," ibid., p.c27-c28.

30. For fuller reports on this and related matters, see Katherine O. Murra, "History of Some Attempts to Organize Bibliography Internationally," in Jesse H. Shera and Margaret E. Egan, eds., Bibliographic Organization (Chicago: Univ. of Chicago $\mathrm{Pr}$., 1951), p.24-53; and Edith Scott, "IFLA and FID-History and Programs," Library Quarterly 32:1-18 (Jan. 1962).

31. Budd Gambee, "Great Junket: American Participation in the Conference of Librarians, London, 1877," Journal of Library History 2:9-44 (Jan. 1967).

32. Library Journal 18:278 (Aug. 1893).

33. K. Dziatzko, "The International Mutual Relations of Libraries," Library Journal 18: 465-68 (Nov. 1893).

34. O. Hartwig, "The Interchange of Manuscripts Between Libraries," Library Journal 18:503-505 (Dec. 1893).
35. International Library Conference, $2 \mathrm{~d}$, London, 1897, Transactions and Proceedings (London: 1898); see also the report in $\mathrm{Li}$ brary Journal 22:391-408 (Aug. 1897).

36. Congrès International des Bibliothécaires, Paris, 1900, Procès-verbaux et Mémoires (Paris: 1901); see also Plummer's report in Library Journal 25:580-82 (Sept. $1900)$.

37. The proceedings, including formal papers, appear in the Conference Issue of Library Journal 29 (1904).

38. Congrès International des Archivistes et des Bibliothécaires, Brussels, 1910, Actes (Brussels: 1912); "The International Library Congresses at Brussels," Library Journal 35:442-60 (Oct. 1910).

39. Congrès International des Bibliothécaires et des Bibliophiles, Paris, 1923, Procèsverbaux et Mémoires (Paris: Jouve, 1925).

40. Congrès International des Bibliothécaires et des Amis du Livre, Prague, 1926, Procès-verbaux et Mémoires (Prague: Imp. d'Etat, 1928-1929), 2 vols.; Ladislav Jan Zivny, "The Prague International Congress," Library Journal 52:304-6 (March 15,1927 ).

41. The discussions and decisions, relating to the founding of IFLA, at Prague, Philadelphia and Washington, and Edinburgh are brought together as "Travaux Préparatoires," p.1-15, together with the initial Actes du Comité International des Bibliothèques (International Federation of Library Assns. Publications, No. 1, Uppsala, 1931).

42. ALA Bulletin 20:175-643 (Oct. 1926).

43. "The Jubilee Conference," Library Association Record ser. 2, 5:249-52 (Dec. 1927).

44. The more specialized types of international library conferences, such as for medical, music, and law libraries, do not quite fit into this article; and FID, as has been indicated, is a bit aside from the mainstream of general American librarianship.

45. For LC, see John G. Lorenz and others, "The Library of Congress Abroad," Library Trends 20:548-76 (Jan. 1972).

46. Robert Vosper, official letter to Florence Anderson, Secretary of the Carnegie Corp., reprinted as Appendix S, p.76-80 in Association of Research Libraries, Minutes, 65th meeting, Jan. 24, 1965, Washington, D.C.

47. Arthur T. Hamlin, "The Trip to Cuba," ALA Bulletin 50:527-28 (Sept. 1956).

48. Foster Mohrhardt, "Dr. William Warner Bishop, Our First International Librarian," Wilson Library Bulletin 32:207-15 (Nov. 1957). 
49. Ernest Cushing Richardson, "International Library Co-operation and Our Local Problems," p.131-44 in his Some Aspects of International Library Co-operation (Yardley, Pa.: F. S. Cook \& Son, 1928).

50. For example, E. C. Richardson, "The Brussels Institute Againl" Library Journal 52: 795-801 (Sept. 1, 1927).

51. E. C. Richardson, "Federation and Co-operation," Library Journal 26:123 (March 1901).

52. William Warner Bishop, "International Relations: Fragments of an Autobiography," Library Quarterly 19:270-84 (Oct. 1949); see also Mohrhardt, "Dr. William Warner Bishop."
53. Igino Giordani, "The Vatican Library During Recent Years," Library Quarterly 7:125 (Jan. 1937).

54. Ibid., p.6.

55. Beverly J. Brewster, American Overseas Library Technical Assistance, 1940-1970 (Metuchen, N.J.: Scarecrow, 1976); also useful are the several articles in Library Trends 20 (Jan. 1972), devoted to "The Influence of American Librarianship Abroad."

56. Brewster, American Overseas Library Technical Assistance, p. 306-7.

57. Richardson, "International Library Co-operation."
Robert Vosper is professor in the Graduate School of Library and Information Science and director of the William Andrews Clark Memorial Library at the University of California, Los Angeles.

